\title{
The Ability of Phytoremediator Mustard (Brassica juncea) to Reduce the Level of Lead $(\mathrm{Pb})$ in Soil
}

\author{
Burhan Muslim ${ }^{1}$ \\ ${ }^{1}$ Department of Environmental Health, Polytechnic of Health Padang, West Sumatera, Indonesia 25146 \\ Email: burhan.muslim@yahoo.co.id
}

\begin{abstract}
Some studies have shown that levels of $\mathrm{Pb}$ in the groundwater around the highway positive containing $\mathrm{Pb}$. This study aims to determine the ability of mustard (Brassica juncea) reduce levels of lead in the soil. This research uses experimental pre and post design. The object of this study is $\mathrm{Pb}$ in soils with mustard planting treatment to reduce levels of $\mathrm{Pb}$. Implementation research held by making a planting medium that has been contaminated with $\mathrm{Pb}$ (NO3) 2. Then in the planting medium mustard planted as many as 10 polybags for a month. Statistical analysis was performed using the t test statistical test to see any significant difference before and seudah $\mathrm{Pb}$ planted with mustard. The results showed behwa Brassica juncea has the ability to reduce levels of lead in the growing media in the range of 9.8 to 13.3\%. Of the statistical tests can be concluded that mustard (Brassica juncea) plants have the ability to significantly reduce levels of $\mathrm{Pb}$ contained in the soil.
\end{abstract}

Keywords. Phytoremediation, Lead (Pb), Brassica juncea,

\section{INRUDUCTION}

\section{Background}

The use of premium fuel is increasing from time to time. Such improvements lead to increased $\mathrm{Pb}$ deposits in the ground along the highway in both urban and rural areas. Elevated levels of lead in the soil affects the levels of lead in ground water consumed by the people, which in turn can accumulate in organs. Some research has been done indicating the that the levels of lead in ground water is already quite high.

Research conducted by Athena, et al in the Greater Jakarta region showed the range levels of lead in ground water between 0.5 to $0.6 \mathrm{ppm}$. This figure is quite high because of the levels of lead in raw water required is $0.03 \mathrm{mg} / 1$. The high $\mathrm{Pb}$ in ground water can come from natural sources and man-made sources. Artificial sources derived from premium fuels containing $\mathrm{Pb}$.

The presence of $\mathrm{Pb}$ in the groundwater can be came from various sources, among others, comes from motor vehicles that accumulate in the soil. Furthermore $\mathrm{Pb}$ in the soil into the water. $\mathrm{Pb}$ contents were high in water consumption can have a negative impact on human health. High levels of $\mathrm{Pb}$ which will accumulate in the blood and central nervous system. $\mathrm{Pb}$ buildup in the brain tissue causing chronic diseases.

$\mathrm{Pb}$ is a heavy metal which is highly toxic and are not needed by humans, so that when food is contaminated by metals, the body will remove it. In the human body, $\mathrm{Pb}$ could inhibit the activity of an enzyme involved in the formation of hemoglobin $(\mathrm{Hb})$ and a small portion of $\mathrm{Pb}$ is excreted through urine or feces as most are bound by protein, while others accumulate in the kidneys, liver, nails, fat tissue, and hair (Widowati, 2008). One option to overcome the problem of contamination by the use of $\mathrm{Pb}$ is bioremediation microbes (Suhendrayatna, 2001).
Remediation action is necessary so that contaminated land can be reused for various activities safely.

Bioremediation is the development of environmental biotechnology field by utilizing biological processes in controlling pollution and quite interesting. In addition to costeffective, can also be performed in situ directly on the spot and a natural process (Erman, 2006). The rate of microbial degradation to heavy metals depends on several factors, including the activity of microbes, nutrients, acidity and environmental factors (Donlon, 2006). Bioremediation technologies there are two types, namely ex-situ and in situ. Exsitu is the management that includes physical transfer of contaminated materials to a location for further treatment (Vidali, 2001). The use of bioreactors, land treatment (land farming), composting and some other forms of solid-phase treatment is an example of ex-situ technology, whereas in situ technology is directly applicable to the treatment of the materials of contaminants in polluted locations (Vidali,

Decreased levels of lead in the soil can be done with phytoremediation, using plants accumulator. Various plants have the ability to accumulate $\mathrm{Pb}$ through various processes that occur on the roots of plants. Each plant has a different ability to accumulate metals in the soil. Some types of plants are known to accumulate is Rice, water hyacinth and mustard. (Brassica juncea) or mustard is one of the plants that have characteristics that can be expected to have the ability to accumulate metals in the soil. This plant is relatively easy to grow and has a rapid growth. Based on these descriptions, the research to determine the ability Barassica juncea in lowering levels of lead in the soil needs to be done. Based on the previous description then that becomes the problem in this poenelitian is (1) How many levels of lead in the soil before planting with Brassica juncea ?, (2) What is the level of lead in the soil after planting with Brassica juncea? (3) Are there differences in 
levels of $\mathrm{Pb}$ in the soil before and after planted with Brassica juncea for 1 month?

\section{Purpose}

a. Discovered that the average level of lead in the soil before planting with mustard (Brassica juncea) for 1 month

b. Discovered that the average level of lead in the soil after planting with mustard (Brassica juncea) for 1 month.

c. Known differences in average levels of lead in the soil before and after planting with mustard (Brassica juncea)

\section{LITERATURE REVIEW}

\section{Heavy Metals in Soil}

Ecologically, the soil is composed by three groups of material, that material living (biotic factors) in the form of biota (the bodies biological), abiotic factors such as organic materials, and abiotic factors such as sand, silt and clay. Generally, about $5 \%$ are making up ground biomass biotic and abiotic (Hanafi, et.al.2003).

Disposal of waste to the land if exceeding the ability of soil to digest the waste will result in contamination of the soil. Type imbah potentially environmentally damaging waste is included in the hazardous and toxic waste in which there are heavy metals. Heavy metals are metals that have a density greater than $5 \mathrm{~g} / \mathrm{cm} 3$, such as $\mathrm{Cd}, \mathrm{Hg}, \mathrm{Pb}, \mathrm{Zn}$ and Ni. Heavy metals $\mathrm{Cd}, \mathrm{Hg}$ and $\mathrm{Pb}$ named as non-essential and at certain levels become toxic metal for a living creature (Arnold (1990 in Subowo et al. 1995)

Metal can cause a hazard in living beings. This occurs when metals pollute the environment. Metal certain metals are very dangerous when found in high concentrations in the environment (water, soil and air), because these metals have properties that damage body tissues of living things. Environmental pollution by hazardous metals $(\mathrm{Cd}, \mathrm{Pb}, \mathrm{Hg})$ may occur if one or factories that use these metals to the production process do not pay attention to the safety of the environment (Darmono, 1995).

Communities of soil organisms in addition to play an important role in ecological processes such as nutrient cycling is also a response to disturbances in the environment such as soil contamination from heavy metals and pesticides. Biological systems are very sensitive to degradation had happened though, so that changes in the biological status of the system can be early warning of environmental deterioration (Ansyori. 2004) Heavy metal pollution on the mainland is closely related to air and water pollution. heavy metal particles that fly in the air will be carried away by rainwater that soaks the ground shingga raised land contamination. The content of heavy metals in the soil is naturally very low, unless the soil is already polluted.

\section{Lead $(\mathrm{Pb})$ in the environment}

Lead / lead $(\mathrm{Pb})$ in the soil can be derived from nature itself or the result of human activity. $\mathrm{Pb}$ can be found naturally in the soil. Some areas in Indonesia land lots containing $\mathrm{Pb}$, such as on the island of Bangka. $\mathrm{Pb}$ derived from human activities primarily from the combustion of premium fuel. $\mathrm{Pb}$ in premium intentionally added as an attempt to improve combustion efficiency.

Lead is a kind of bluish-gray metal, has a high density, very soft and easy to melt. Soluble in HNO3, slightly soluble in dilute $\mathrm{HCl}$ and $\mathrm{H} 2 \mathrm{SO} 4$ (Vogel, 1990). The toxicity of lead is differentiated according to the affected organ is some haemopoietic system, central nervous system and the waterfront, the renal system, gastrointestinal system, cardiovascular system, reproductive system, the endocrine system. Lead in the body is mainly tied to the - $\mathrm{SH}$ group in a protein molecule and cause a drag on activity of enzyme systems work. Lead circulates in the blood once absorbed from the intestine, mainly to do with the red blood cells (erythrocytes). Then distributed into the soft tissues such as the kidney tubules and liver cells, and then stored in the bones, hair and teeth, of which $90 \%$ deposit occurs in the bones and only a small portion is stored in the brain (Darmono, 2001).

Lead $(\mathrm{Pb})$ has an important meaning in the world of health is not due to the use of therapy, but rather due to the nature of its toxicity. Absorbtion of lead in the body very slowly, resulting in the accumulation and the basis for a progressive poisoning. Lead poisoning is causing high lead levels in the aorta, liver, kidneys, pancreas, lungs, bones, spleen, testes, heart and brain (Supriyanto, et al., 2007)

Lead emitted from motor vehicle fumes will be in the air and will settle on the ground. Lead in the air can be directly inhaled by humans through inhalation or orally. In general, elementary school children are still often played with the ground, consequently lands have been polluted by lead will stick in their hands. Because the children were often Elementary School did not like to wash their hands before they eat food, then there is a possibility of lead will be absorbed into the human body and also will be in the blood and other organs. This study aimed to explore the link between transport activities (volume of traffic) with the presence of lead $(\mathrm{Pb})$ in the soil. Levels of lead in soil is not contaminated ranging from 2 to $200 \mathrm{ug} / \mathrm{g}$ soil.

Lead $(\mathrm{Pb})$ which enter into the human body can cause various disorders, both acute and chronic. $\mathrm{Pb}$ into the human body can cause damage to nerve tissue, lower learning ability, reduce the function of the kidneys, lowering blood hemoglobin levels, and make children hyperactive.

Emissions of lead $(\mathrm{Pb})$ from the exhaust gases of motor vehicles in addition to polluting the air also contaminate other natural conditions such as water and soil. Lead $(\mathrm{Pb})$ situated in the ground at times can be released into the environment back because eroded by flowing water and carried away by the wind, and some will be absorbed by the roots of plants around it.

\section{Phytoremediation}

Phytoremediation is a system where certain plants that work with micro-organisms in the media (soil, coral and water) can transform contaminant/pollutants into less harmful or even become economically useful materials. Phytoremediation is a method of cleaning the environment (soil, ground water, mud, and sediments) contaminated in the low to medium level, by utilizing the ability of green plants to absorb harmful heavy metals and radioactive substances. The remedial actions 
necessary to ensure contaminated area can be reused for various activities safely. The use of plants in the contaminated areas is a remediation method that is easy, does not require great energy, cost, and is a technique that can be used in the long term.

Therefore, the role of plants as media remediation needs to be studied further. Phytoremediation usage is based on the ability of some plants to accumulate certain radioactive materials so that the concentration in biota is well above the concentration of media cropping which is the entry point tersebut. Radioactive material is absorbed by the roots, experienced translocation in plants and localization in tissues. One of the plants that are metal accumulators is mustard (Brassica juncea) . In mustard plant research will be tested for its ability to absorb radioactive cesium contained in andosol ground, so that the cesium in soil can be appropriated into lower concentrations. Phytoremediation is a technology of cleaning, removal or reduction of harmful pollutants, such as heavy metals, pesticides, and toxic organic compounds in the soil or water with the help of plants (hyper accumulator plant). Each plant has a different ability to absorb pollutants in the soil. Each plant also has the distinct ability to absorb certain types of pollutants. There are plants that can absorb $\mathrm{Hg}$, organic materials, gold, and iron.

The process in this system occurs naturally with six stages in a serial process in which plants against contaminants / pollutants that are around:

a. Phytoacumulation (phytoextraction) is the process plants attract contaminants from the media that accumulates around the plant roots. This process is also called Hyper accumulation

b. Rhizofiltration $($ rhizo $=$ root $)$ is the process of adsorption or pengedapan contaminants by the roots to stick to the roots. Experiments for this process is done by menanan sunflower contains an active radio to a test at Chernobyl, Ukraine.

c. Phytostabilization namely the attachment of certain substances in the roots contaminant who could not be absorbed into the plant stem. These substances clinging (stable) at the root so it will not be carried away by the flow of water in the media.

d. Rhyzo degradation rhezosphere enhenced also called biodegradation, or plented-assisted bioremidiation degradation, ie substances decomposition of contaminants by the activity of microbes which are located around the roots of plants. For example, yeast, fungi and bacteria.

e. Phytodegradation (phyto transformation) is the process in which plants to decompose contaminants that have complex molecular chains into a harmless substance with the molecular composition of a more simpler that can be useful for the growth of the plant itself. This process can take place in the leaves, stems, roots or outside around the roots with the help of enzymes released by the plant itself. Some plants secrete an enzyme in the form of chemicals that accelerate the process of degradation processes. f. Phytovolatization is fascinating process and substance contaminan transpiration by plants in the form of a solution that has been decomposed as the material is not dangerous to the next in uapkan to admosfir. Some herbs may evaporate the water 200 to 1000 liters per day for each trunk.

\section{Brassica juncea (mustard) as phytoremediator}

Mustard is an annual plant. Its form resembles caisim. Caisim mustard and sometimes difficult to distinguish. Oval-leaved mustard greens, soft, lint, and not berkrop. Both types of vegetables can be crossed (interbred). Mustard plant has a short stem and more slender than the chinese cabbage. The main leaf veins more narrow than the chinese cabbage, but the leaves are more pliant. In general, the growth pattern of scattered leaves (rosette) to difficult to establish the crop. This plant has a taproot with many side roots, but shallow. The flowers resemble chinese cabbage, but a series of shorter bunches. Flower bud smaller size with a pale yellow color specific. Small seed size and brownish-black. The seeds are on both sides of the bulkhead wall pods fatter. Almost everyone likes cabbage for the fresh taste (delicious) and contains vitamin A, vitamin $\mathrm{B}$, and a little vitamin C. However, mustard leaves taste slightly bitter. Mustard can be used as a vegetable or fresh vegetables in the form of cooking. Besides green cabbage leaves are also often be pickled by the Chinese community.

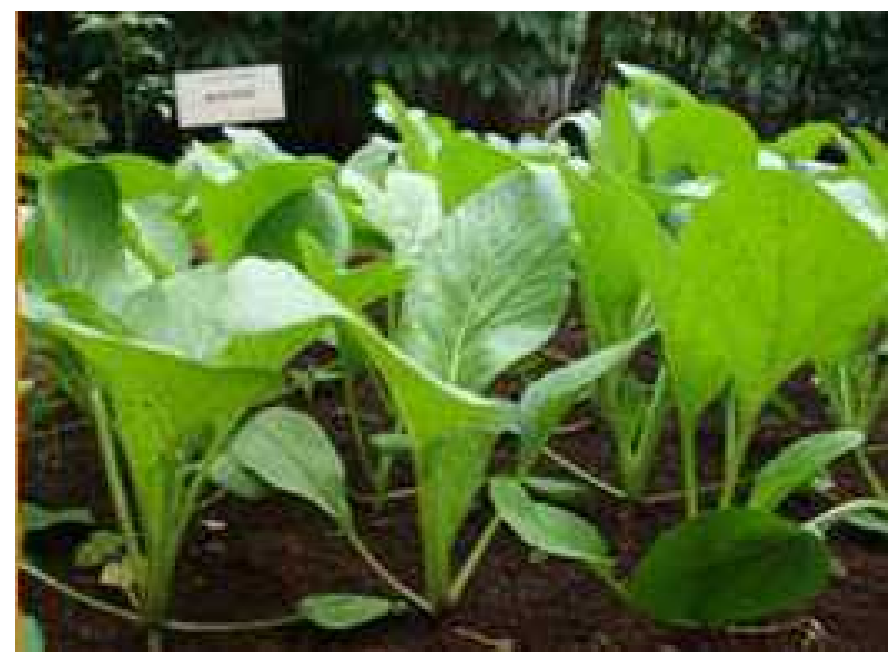

Image: Plant mustard (Brassica juncea L)

How to breed mustard plant is by seed. Farmers can produce their own seeds because this plant is very easy flowering and seeding. -biji Mustard seeds need to be seeded first. For an area of 1 ha, required 700 grams of mustard seed. Before sowing seeds, land processed first, with a depth of $30 \mathrm{~cm}$ hoe and manure as much as 10 tonnes / ha. After that the land made beds-beds with a width of $1 \mathrm{~m}$. The beds were made in the three rows of plants with a spacing of $30 \mathrm{~cm}$ and the distance between rows $40 \mathrm{~cm}$. 
After the age of 3-4 weeks from the time dispersive (approx leafy 4 strands), the seed can be moved to the bed. Furthermore, at the age of 10 days, the plants were given a urea fertilizer plant supplied around $5 \mathrm{~cm}$ from the trunk as much as 3 grams per plant. Thus for an area of $1 \mathrm{ha}, 250 \mathrm{~kg}$ of urea is required. This fertilizer should be given at the same time didangir ground.

Maintenance of mustard plants preferred by controlling the moth attack. This leaves the caterpillars can be eradicated by spraying insecticides, such as Ambush 2 EC, Decis 2,5 EC. Harvesting of mustard can be done after 2 months old. Sawi levied by way plants bgian revoked or cut stems on the ground. There is also levied by way of picking leaves one by one. How such a collection is intended for long-lasting plants. Mustard plants are well maintained and healthy can produce $10-15$ tonnes / ha

Indian mustard plants that have been genetically modified, proved able to absorb the excess heavy metals from soil selenium. This is the first time conducted field trials on transgenic crops repellent metal pollution

Indian mustard plants that have been genetically modified, proved able to absorb the excess heavy metals from soil selenium. This is the first time conducted field trials on transgenic crops repellent metal pollution, and it is hoped this technology could clean up the land in the future.

"Indian mustard is able to grow rapidly despite being in an environment full of pressure," says Norman Terry, a plant biologist at the University of California, Berkeley, who led the study. Because of the ability of scientists chosen as experimental plant. They improve the ability to absorb toxins in mustard by adding extra genes that produce enzymes that "hungry" for selenium.

Various methods have been used to remediate heavy metals in the soil as a way of physics, chemistry and biology. but these methods are considered less effective because contaminants will simply change places. One method for determining the heavy metal pollutants that developed over the past decades is phytoremediation. This method uses plants / herbs to attract heavy metal contaminants from the soil. This method is considered good because it is environmentally friendly and does not damage the soil properties.

From research conducted Asmawati, et al. Juncea Brasiica ability to accumulate metals Cadmium (Cd) showed that the accumulation of cadmium in the highest green mustard plant roots are $165.15 \mathrm{ppm}$ in pot sizes $2.5 \mathrm{~kg}$ and the lowest was $54.70 \mathrm{ppm}$ of the same pot. Cd accumulation in leaves of mustard highest is $125.65 \mathrm{ppm}$ on the size of the pot $0.5 \mathrm{~kg}$ while the lowest was $22.29 \mathrm{ppm}$ on pot size of $2.5 \mathrm{~kg}$. The accumulation of cadmium ions on green cabbage root as a function of $\mathrm{pH}$ was $470.43 \mathrm{ppm}$ at $\mathrm{pH} 7.5$ and the lowest was $211.64 \mathrm{pp}$ on the same $\mathrm{pH}$. On a green cabbage leaf highest cadmium levels are $289.27 \mathrm{ppm}$ at $\mathrm{pH} 7.0$ and the lowest was $61.91 \mathrm{ppm}$ at $\mathrm{pH} 5$.

\section{RESEARCH METHODS}

\section{Research design}

This research uses experimental design with pre and post design approach. Which is to see the difference $\mathrm{Pb}$ in soils used as a growing medium before and after planting with mustard (Brassica juncea) for one month.

\section{Place and Time}

This research was conducted in Padang. The treatment object of research done at the Regional Military Complex Block I No. 7 Padang. While examination of soil samples containing $\mathrm{Pb}$ carried out in laboratories Health Laboratory West Sumatra, Padang. The Research carried out for 5 months, from June to October 2015

\section{Research Object}

The object of this study is the level of lead $(\mathrm{Pb})$ in soil were derived using mustard (Brassica juncea) as phytoremediator.

\section{Variables and Operational Definitions}

The variables in this study are:

a. Levels of lead in the soil before planting with mustard (Brassica juncea) with units of $\mathrm{Mg} /$ gram of soil.

b. Levels of lead in the soil after planting with mustard (Brassica juncea) for 1 month with units of $\mathrm{mg} /$ gram of soil.

\section{Data Collection}

Collecting data in this study is done by measuring levels of lead in soil by using SAA. (Spectrophotometer Atomic Absorption).

\section{Materials and Methods Research \\ Preparation of planting medium}

a. Prepared topsoil mixed with compost mixed evenly by about $25 \mathrm{Kg}$.

b. $\mathrm{Pb}$ pollutant prepared by weighing 30 grams of $\mathrm{Pb}$ (NO3) 2 and then dissolved in 1 liter of distilled water.

c. Then the planting medium contaminated with a solution of $\mathrm{Pb}$ (NO3) 2 which has been made and then stirred with a flat back, and left for 24 hours.

d. Media cropping put into polybag diameter of $20 \mathrm{~cm}$ by 10 pieces weighing $2 \mathrm{~kg}$ each.

\section{Examination of $\mathrm{Pb}$ in the planting medium}

Soil samples were taken at each of polythene bags to be checked in West Sumatra Health Laboratory.

\section{Preparation of a mustard seed}

Prepared mustard seed mustard purchased from farmers in Padang Panjang age 1 month in seedlings.

\section{Planting mustard}

a. Mustard seed planted in polybags ten pieces that have been provided, each consisting of one cigarette polybag collards, while one polybag left kosang as controls.

b. Mustard plants are watered once a day for a month, including control 
The level of lead in the soil after planting mustard

a. Mustard plants in pots revoked

b. Former land plants in each polybag stirring to evenly sampled.

c. Do paemeriksaan $\mathrm{Pb}$ in the soil after planting mustard for one month in Health Laboratory West Sumatra.

\section{Processing and Data Analysis}

The data were processed using a computer application program. Measurement data of each polybag included in the application program, then searched the average. Furthermore, to significantly decrease the occurrence mengathui t test dependent.

\section{RESULT AND DISCUSSION}

\section{Result}

\section{Levels of lead in the soil before planting Brassica juncea}

Land that is used as a growing medium in advance has been contaminated with the compound $\mathrm{Pb}$ (NO3) 2 dissolved in aqudest. The planting medium is included in a polybag with 10 pieces each weighing $2 \mathrm{~kg}$. Polybag which already contain the growing medium, left for 2 days of growing media samples taken from each polybag and soil samples taken at each polybag to analyze $\mathrm{Pb}$ before planted with Brassica juncea. Test results $\mathrm{Pb}$ planting medium before planting mustard greens can be seen in Table 1 below:

Table 1. Pb levels in the growing media before planting Brassica juncea

\begin{tabular}{ccccc}
\hline $\mathrm{n}$ & Max & Min & Avg & $\mathrm{S}$ \\
\hline 10 & 542 & 520 & 533 & 7,49
\end{tabular}

Table 1 shows that the highest levels of $\mathrm{Pb}$ planting medium is $542 \mathrm{ppm}$, the lowest levels of $520 \mathrm{ppm}$, an average of 533.4 with a standard deviation of $7.49 \mathrm{ppm}$.

\section{Levels of lead in the soil after planting Brassica juncea}

$\mathrm{Pb}$ levels in the growing media re-tested after planted with Brassica juncea for a month. After a month, mustard plant in polybags revoked later planting medium evenly stirred, then each taken sampenya tested in a laboratory.

Results of testing $\mathrm{Pb}$ content in the growing media after planted with Brassica juncea can be seen in Table 2 below:

Table 2. Pb levels in the growing media after planted Brassica juncea For a month

\begin{tabular}{ccccc}
\hline $\mathrm{n}$ & Max & Min & Avg & $\mathrm{S}$ \\
\hline 10 & 488 & 454 & 469 & 11,1
\end{tabular}

Table 2 shows that the levels of lead in the growing media after planted Brassica juncea highest is 475 ppm, 454 ppm lowest, average 469, 4 ppm and standard deviation of $11.1 \mathrm{ppm}$.

\section{Reduction of $\mathrm{Pb}$ levels after planting Brassica juncea}

The reduction of $\mathrm{Pb}$ levels after planting Brassica juncea, can be seen in Table 3 below:

Table 3: Reduction of $\mathrm{Pb}$ after planted Brassica juncea

\begin{tabular}{cccc}
\hline & Before & After & \% of reduction \\
\hline Max & 542 & 488 & \\
Min & 520 & 454 & \\
Avg & 533,4 & 469,4 & $12 \%$ \\
S & 7,9 & 11,1 & \\
\hline
\end{tabular}

Table 3 shows that the average decline in the levels of $\mathrm{Pb}$ after planted Brassica juncea is at $12 \%$.

The Test of average difference using paired sample t test is known that there are significant differences in the average level of lead in the growing media before and after planting with the Brassica juncea, with a confidence level of $95 \%$.

\section{Discussion}

\section{Pb levels before planting mustard}

$\mathrm{Pb}$ levels in the growing media before planting mustard greens are relatively homogeneous, ie from 10 growing media tested, the highest level $542 \mathrm{ppm}$ occurs and the lowest levels of 520 ppm, with a standard deviation of $7.49 \mathrm{ppm}$.

$\mathrm{Pb}$ in the planting medium made by contaminating with a compound $\mathrm{Pb}(\mathrm{NO} 3)_{2}$ dissolved in distilled water. $\mathrm{Pb}$ is still not the same for all polybags can occur because of the inequality stirring, so that the distribution of $\mathrm{Pb}$ compounds into the planting medium unevenly across perfectly. Nevertheless $\mathrm{Pb}$ levels are relatively homogeneous, characterized by the standard deviation .

\section{Levels of $\mathrm{Pb}$ after planting mustard}

$\mathrm{Pb}$ growing media after planted with Brassica juncea for a month is more diverse than the $\mathrm{Pb}$ before planting. This is evident from the figures obtained. The highest levels are 475 $\mathrm{ppm}$, while the lowest levels of $\mathrm{Pb}$ is $454 \mathrm{ppm}$. Average $\mathrm{Pb}$ to the growing media after planted Brassica juncea, is equal to $469 \mathrm{ppm}$, with a standard deviation of $11 \mathrm{ppm}$.

Variations $\mathrm{Pb}$ growing media after planted Brassica juncea is largely determined by the characteristics of the plant. The number of strands and roots and leaf area is a critical role. Both parts will determine the amount of lead that can be absorbed 
and distributed to the leaves. In this study, both of these plants vary widely. Some one who has a lot of roots and leaves are numerous and widespread, while others have roots and leaves a little bit anyway. With these variations, the amount of lead that can be absorbed from the growing media also varies.

\section{Reduction of $\mathrm{Pb}$ levels before and after planting mustard}

$\mathrm{Pb}$ content variation in the planting medium stelah planted Barssica higher juncea characterized by the value of a higher standard deviation. Variations $\mathrm{Pb}$ to the growing media before planting Brassica juncea is only determined by the inequality stirring when the addition of $\mathrm{Pb}$ into the planting medium. In other words that there are many factors that play a role in $\mathrm{Pb}$. $\mathrm{Pb}$ levels in the growing media after planted with Brassica juncea affected by variations Brassica juncea plant itself, which includes among others the size of leaves, number of roots, leaves Tangkau size and vitality. From the observation of growth Brassica juncea found any differences in physical characteristics of Brassica juncea after being planted for a month in a polybag.

Decreased levels of metals in the soil by phytoremediation process involves a variety of processes, namely phytoacumulation (phytoextraction), Rhizofiltration (rhizo = root), Phytostabilization, Rhyzodegradetion, and Phytovolatization.

\section{CONCLUSION AND SUGGESTIONS}

\section{Conclusion}

a. Levels of $\mathrm{Pb}$ planting medium before planting Brassica juncea highest is $542 \mathrm{ppm}$, the lowest levels of $520 \mathrm{ppm}$, an average of $533.4 \mathrm{ppm}$ with a standard deviation of 7.49 ppm.

b. Levels of lead in the growing media after planted Brassica juncea highest is 475 ppm, 454 ppm lowest, average 469, 4 ppm and a standard deviation of $11.1 \mathrm{ppm}$.

c. There is a significant difference in the average level of lead $(\mathrm{Pb})$ in the growing media before and after planted with Brassica juncea for one month.

\section{Suggestions}

a. Need to do further research to find out which parts of Brassica juncea that has the ability to accumulate $\mathrm{Pb}$.

b. It should be further research to know the ratio of Brassica juncea ability to absorb $\mathrm{Pb}$ with other plants.

\section{BIBLIOGRAPHY}

Ali M., Rina. 2010. Plant Mangrove Ability To Absorb Heavy Metals Mercury ( $\mathrm{Hg}$ ) and lead ( $\mathrm{Pb} 2+)$. Veterans National Development University. East Java.

Alloway, B.J. 1995. Heavy Metals in Soils. Blackie Academic and Professional, Chapman \& Hall, second edition.
Amanda, J.Z; David. C.W 2010, Heavy Metal and Trace Metal Analysis in Soil by Sequential Extraction: A Review of Procedures, International Journal of Analytical Chemistry, Hindawi Publishing Corportion

Asmawati, A; Taba, P; Liong, S, 2010. Remediation of Soil Contaminated Metal Cadmium Using Plants Green Mustard (Brassica juncea), UNHAS Repository, accessible via http://repository.unhas.ac.id/handle/123456789/2667

Donlon, D.L. and Bauder, J.W. A General Essay on Bioremediation of Contaminated Soil, http://waterquality.montana.edu/docs/methane/Donlan. shtml [6/06/2011]

Erny, Y .; Dwi, N.S; Rasti, S., 2003. Collection, Characterization and Preservation of Microbial Remediation, Proceedings of Pioneering Research Seminar and Plant Biotechnology

Erman, M. 2006. Utilization of Microbes in Bioremediation an Alternative Technology for Environmental Preservation. USU respository

Gao, M .; Liang, F .; Yu, A .; Li, B .; Yang, L, 2010. Evaluation of stability and maturity during the forced-aeration composting of chicken manure and sawdust at different $\mathrm{C} / \mathrm{N}$ ratios, Elsevier.

Gottsching, L; Pakarinen, H, 2000. Recycled Fiber and deinking, Papermaking Science and Technology, publisher of TAPPI.

Hardiani.H. 2008 "Contaminated Land Restoration B3 waste from deinking process In Phytoremediation Paper Industry", Journal of Industrial Research. Vol. 2. 2. August 2008, ISSN. 1978-5852, Hal. 64-75.

Hidayati, N., Fauzia, S., Titi, J. 2005. Potential Centrocema pubescence, Colopongium mucunoides, and Micania cordota in Metal Cleaning \ contaminants In Gold Mining Waste. Bogor: Biology Research Center, Indonesian Institute of Sciences (LIPI).

Huang, D. L., Guang M.Z., Xiao, Y.J., Chong, L.F., Hong, Y.Y., Guo, H.H., Hong, L.L., 2005. "Bioremediation of Contaminated soil $\mathrm{Pb}$ by incubating with Phanerochaete chrysosporium and 